ارزيابى توان دكر آسيبى عصارهى آبى بومادران (Achillea wilhelmsii) بر جوانهزنى و رشد

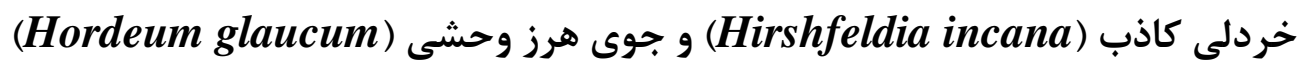

زهرا محمدز اده نصر آباد عليا '، احمد مهتدى r،

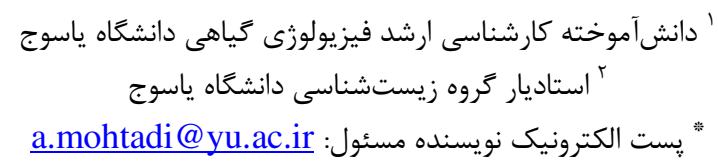

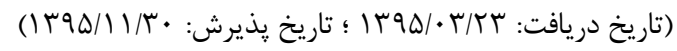

جكيده

علفهاى هرز تهديد جدى براى كشاورزى محسوب مى شود. استفاده از ويزگى دتر آسيبى تياهان بهويزه

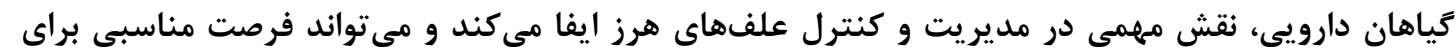
رييدايش علفكشهاى طبيعى و نسل جديدى از بازدارندههاى رشد باشد. اين تحقيق بهمنظور بررسى توان

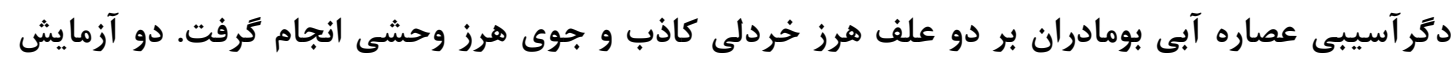

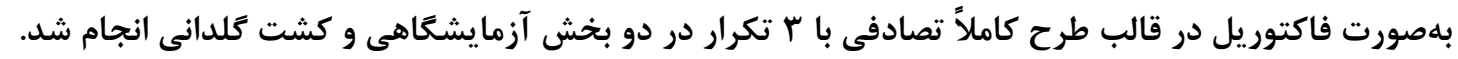

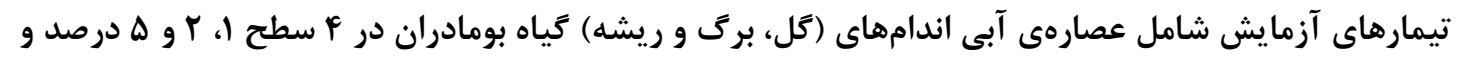

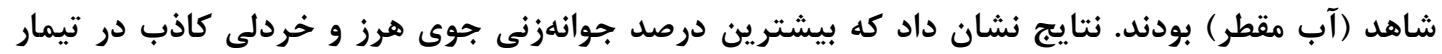

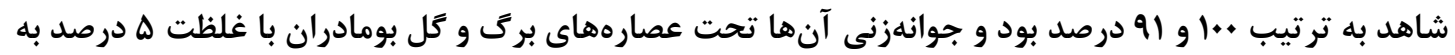

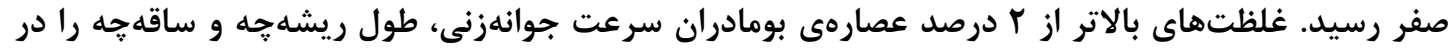
جوى هرز وحشى و خردلى كاذب بهطور معنى دارى نسبت به شاهد كاهش داد. بر اساس يافتههاى اين تحقيق

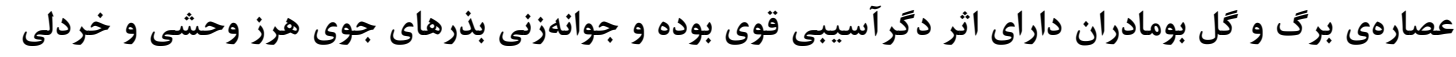

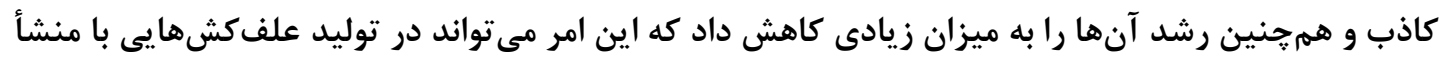
طبيعى مورداستفاده قرار كيرد.

وازههاى كليدى: بومادران، جوى هرز وحشى، خردلى كاذب، علفكش طبيعى، تياه دارويى

جنبههاى نوآورى:

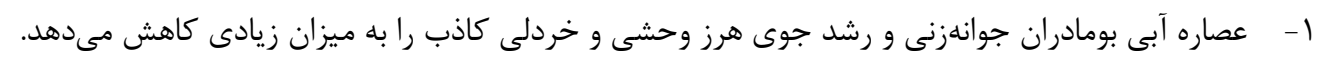

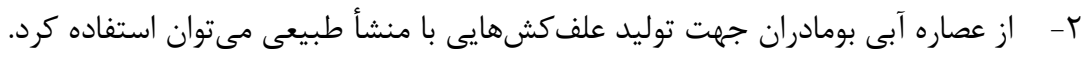

آفات، بيمارىها و علفهاى هرز نيز مى گردند؛ بنابراين مقدمه ادامهى روشهاى كشت متداول باعث نابودى منابع، شتاب فزايندهى افزايش جمعيت در جهان، وابستكى

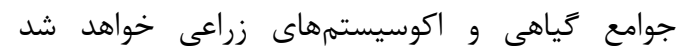

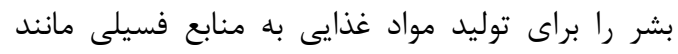

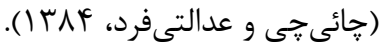

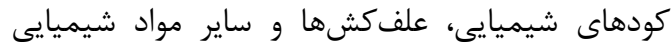
از طرفى علفهاى هرز تهديد جدى برى براى كشاورزى

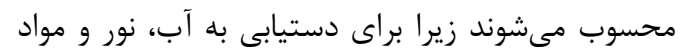

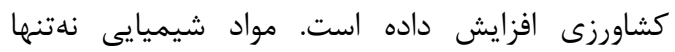

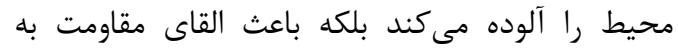


(L.

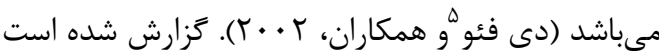

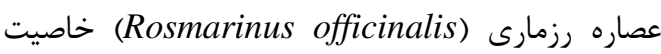

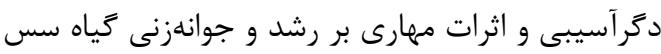
(Cuscuta campestris)

$(T \cdot 14$

جنس بومادران (Achillea) يكى از مهمترين جنسهاى خانواده كاسنى (Asteraceae) است. اين إن

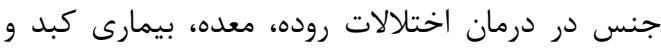

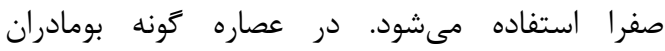
Gr (Achillea wilhelmsii)

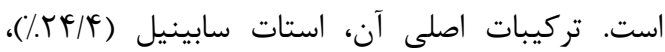

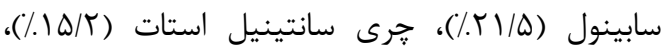

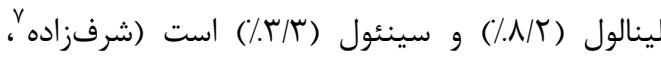
$(r \cdot 1)$

با توجه به اين كه كياهان خردلى كاذب و جوى هرز

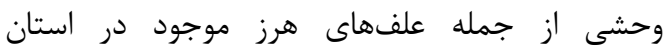

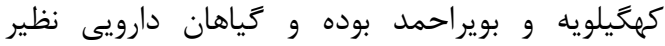

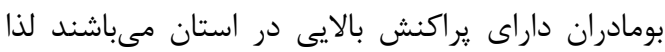

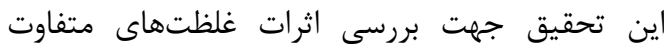

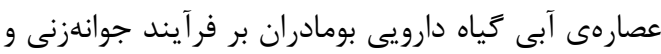

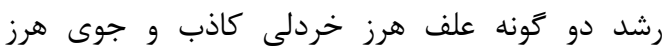
وحشى بهعنوان يكى علفكش زيستى جهت مرنى مهار آنها

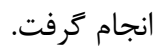

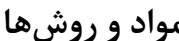

يزوهش حاضر در آزمايشحاه فيزيولوزى كياهى

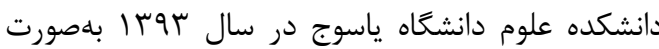

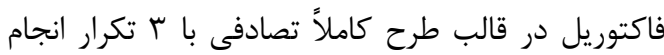
كرفت. تيمارها در مرحلهى جوانهزنى شامل غلظتهاى

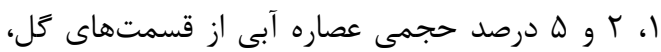

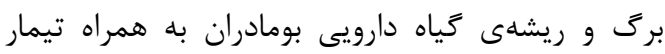
شاهد (آب مقطر) بود كه غلظتهاى متفاوت عصاره آبى ديى دآي

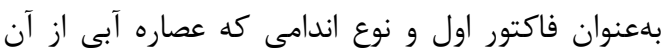

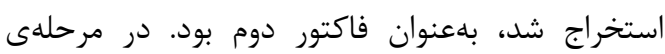

\footnotetext{
${ }^{5}$ De Feo

${ }^{6}$ Hassannejad and Ghfari

${ }^{7}$ Sharafzadeh
}

غذايى با كياهان زراعى رقابت كرده و باعث كاهش كمى

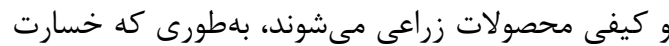

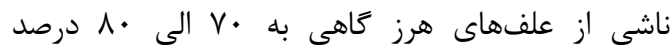

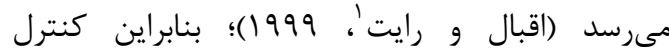

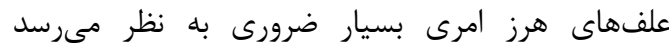

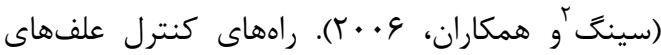

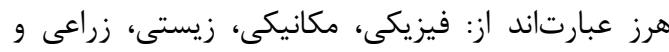
شيميايى كه در اين ميان مبارزمى شيميايى بلعنوان

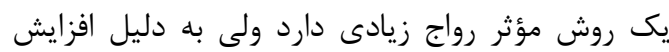

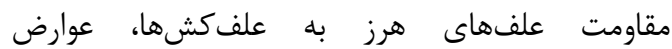
زيستمحيطى و آلودگى آبهاى سطحى و و زيرزمينى،

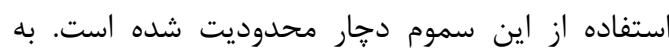

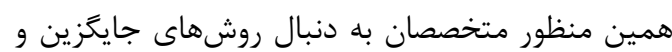
دوستدار طبيعت براى كنترل علفهاى هرز و كاربرد

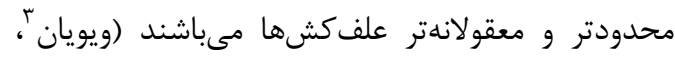

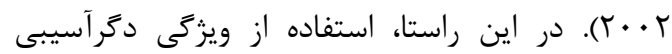

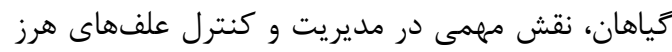
ايفا مىكند و مىتواند فرصت مناسبى براى پِيدايش

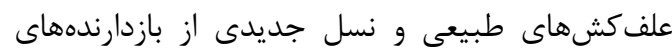
رشد باشد (حجازى،

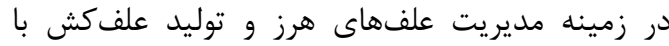
منشأ كياهى كه كمترين آسيب را بر بر اكوسيستم وارد كند، انجام كرفته است. استفاده از خاصيت دَرآسيبى

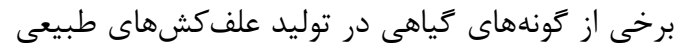
(كه نسبت به علف كشهاى مصنوعى اختصاصىتر عمل كرده و عوارض نامطلوب كمترى دارند) يكى از روشهاى إنهاى يُيشنهادى بهمنظور كاهش مصرف سموم شيميايى است.

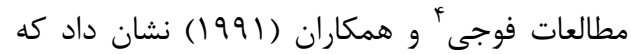

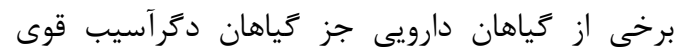

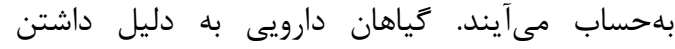

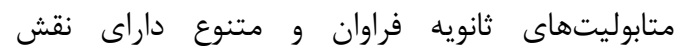

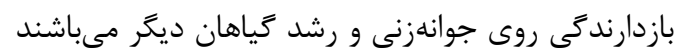

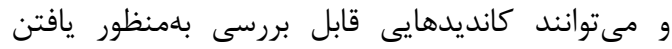
علفكشهايى طبيعى باشند. براى مثال نشان داده شده است كه عصاره گياه دارويى سداب ( Ruta graveolens

\footnotetext{
${ }^{1}$ Iqbal and Wright

${ }^{2}$ Singh

${ }^{3}$ Vyvyan

${ }^{4}$ Fujii
} 
t تعداد بذور جوانهزده تازمان = n

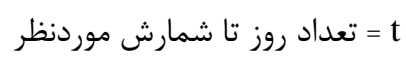

درصد جوانهزنى بذرها نيز با استفاده از رابطهى زير مودري

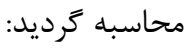

(n/N)×100 = درصد جوانهزنى

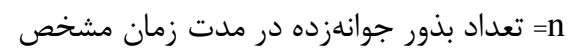

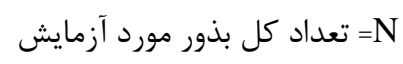

در بخش كشت كلدانى واحدهاى آزمايشى شامل

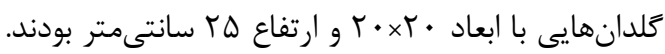

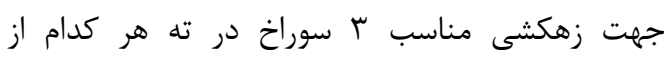

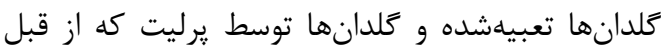

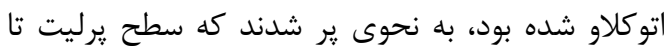

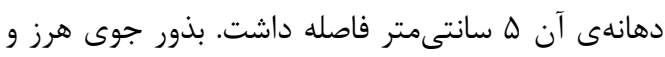

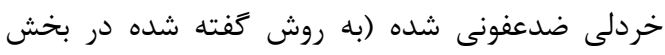
قبل) در كلدانها كشت شدند.

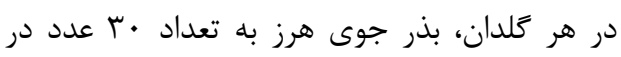

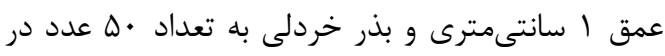

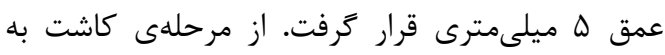

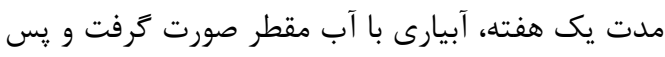

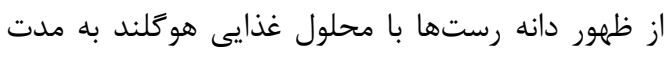

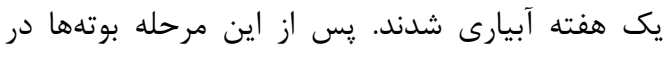

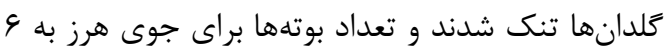
و براى خردلى به ه عدد تقليل يافت.

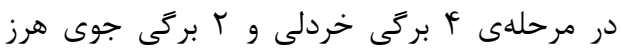

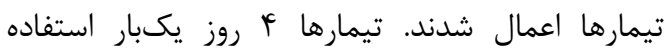

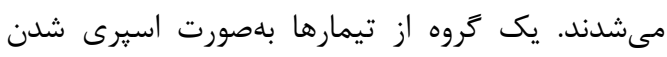

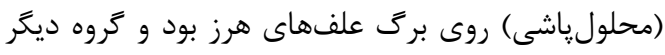

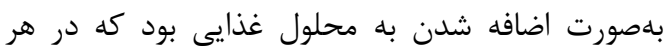

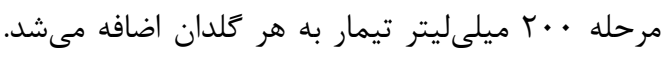

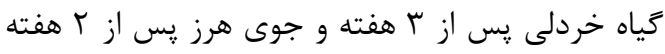

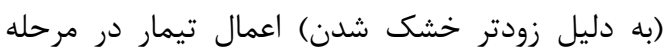

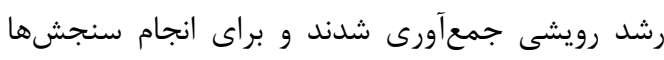

استفاده شدند.

در نهايت شاخص كلروفيل برك با دستخاه اسياد

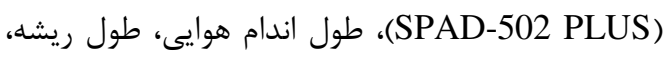

$$
\text { وزنتر، وزن خشك و سطح برك اندازهخيرى شدند. }
$$

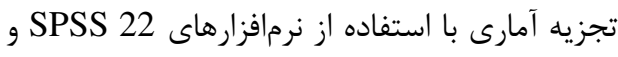
رسم نمودارها با Excel و مقايسه ميانكَين دادهها از لرمان
كشت كَلدانى نيز فاكتورهاى آزمايش شامل ^ غ غلظت

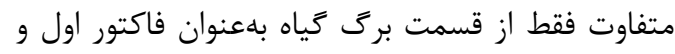

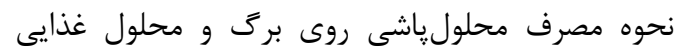
بهنوان فاكتور دوم بود. بامنظور تهيه عصاره آبى، كَياه

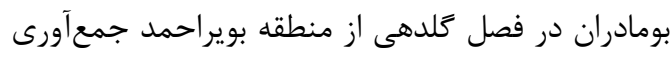

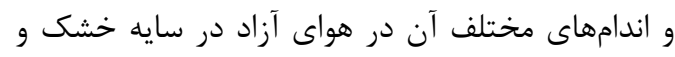

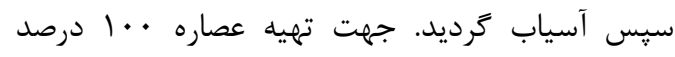

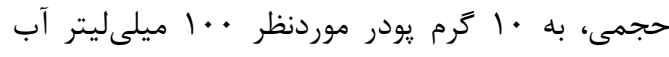

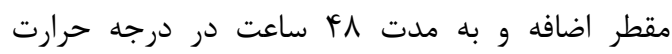

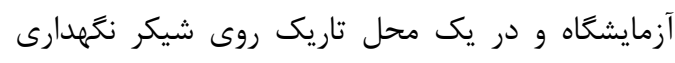

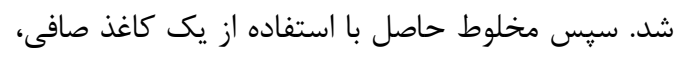

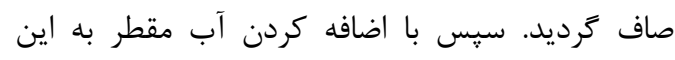

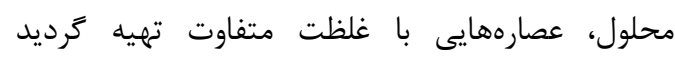

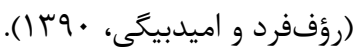

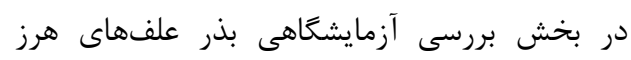

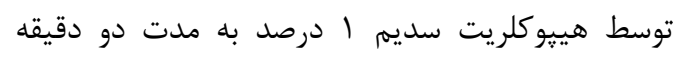

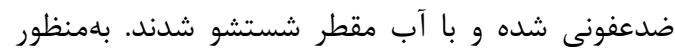

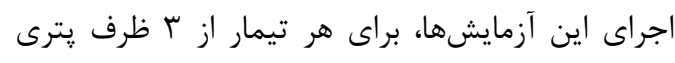

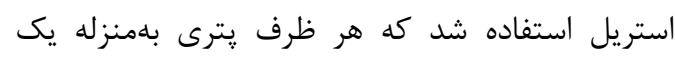

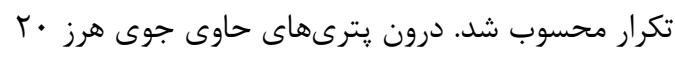

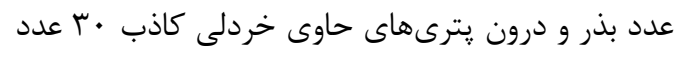

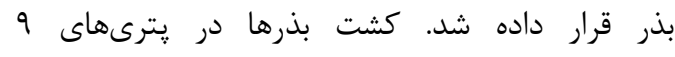

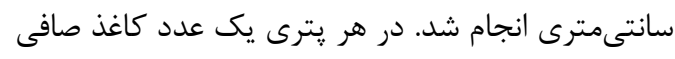

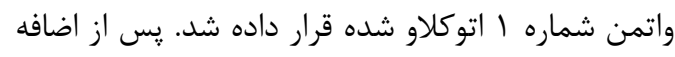

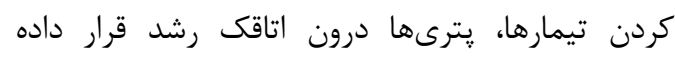

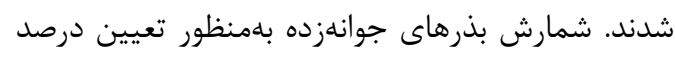

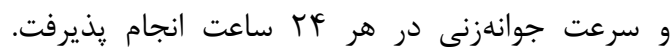

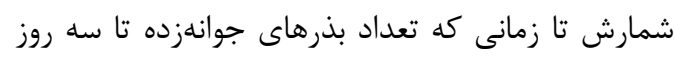

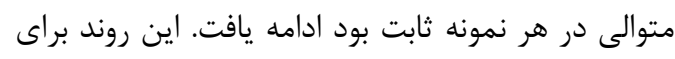

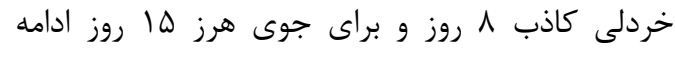

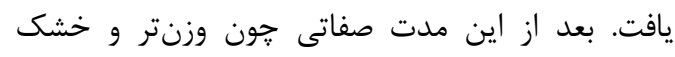

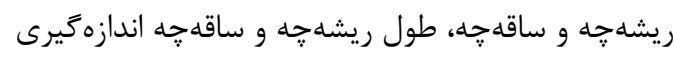

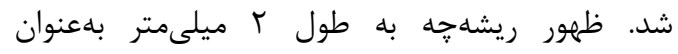
جوانهزدن بذر تلقى گرديد.

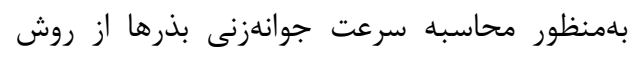
ماكوير' (9\&Y) (9) و از رابطه زير استفاده شد: (n/t)

\footnotetext{
${ }^{1}$ Maguire
} 


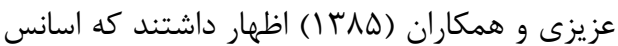

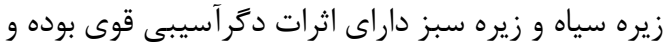
باعث كاهش جوانهزنى سه تَّنه علف هرز

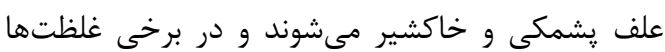

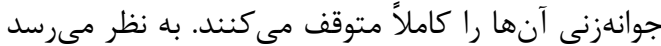

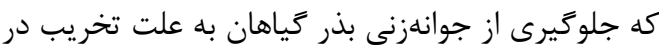

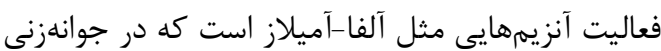

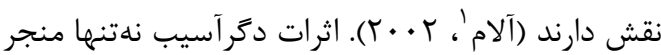

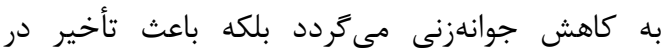

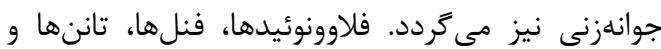
كليكوزيدها را بهعنوان تركيبهاى بازدارندهى جوانهزنى

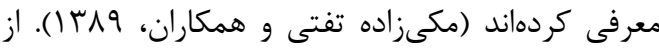
آنجا كه كَونه بومادران دارى تركيبات متابوليتى ثانويه از

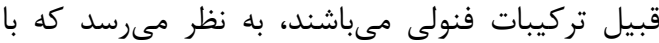
آزاد كردن اين تركيبات باعث كاهش جوانهنيات فئ شدهاند

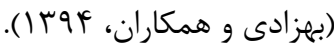

\section{تأثير عصاره تياه بومادران بر طول ريشهجه و ساقهجه}

نتايج نشان داد كه سطوح مختلف عصاره كياه

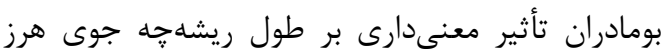
وحشى خردلى كاذب در سطح احتمال خطاى يكى نائى درصد داشت (جدول ץ). بر اساس نتايج به دست آمده شاهد بيشترين و تيمار ه درصد كمترين طول ريشهجه

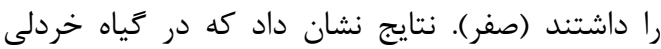

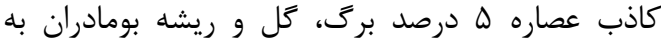

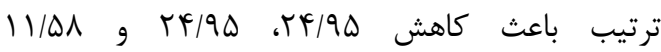
ميلىمترى طول ريشهجه نسبت به شاهد شد.
طريق آزمون جند دامنهاى دانكن در سطح احتمال ه

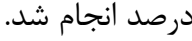

نتايج و بحث تأثير عصارهى تياه بومادران بر درصد و سرعت

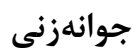

نتايج آناليز واريانس نشان داد كه برهمكنش نوع عصاره و غلظت براى تمامى صفات مورد بررسى معنى دار

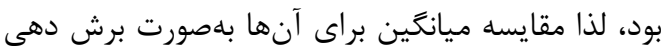
انجام شد. نتايج نشان داد كه درصد جوانهزنى جوى هرز وحشى و خردلى كاذب، در سطوح مختلف عصاره كَياه بومادران، تفاوت معنىدارى در سطح احتمال خطاى يك درصد داشت. نتايج اثر غلظتهاى مختلف عصاره كل بومادران همانند عصاره برك آن مىباشد. بهَّونهاى كه

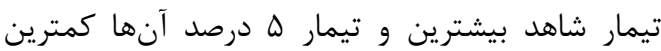
درصد جوانهزنى را داشتند. نتايج براى عصارهى ريشه در كياه جوى هرز وحشى نشان داد تيمار له درصد نسبت

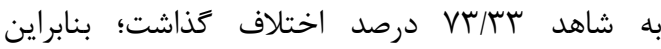

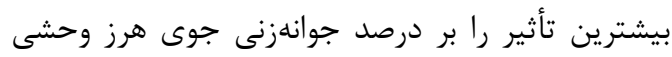
عصاره كل و برى و كمترين تأثير را عصاره ريشه بومادران داشت (جدول ()). در زياه خردلى كاذب در دران عصاره ريشه، بيشترين درصد جوانهزنى براى شاهد و وردان

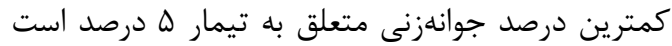

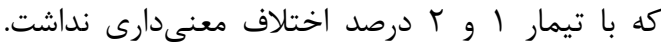

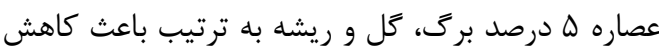

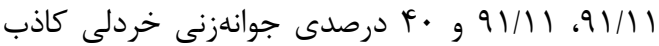

نسبت به شاهد شد (جدول ().

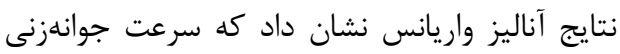
جوى هرز وحشى و خردلى كاذب، در سطوح مختلف

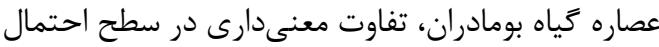
خطاى يك درصد داشت. نتايج حاكى از آن بود كه

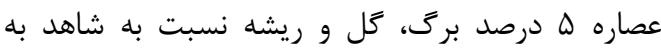
ترتيب باعث كاهش در روز) سرعت جوانهزنى جوى هرز وحشى شد (جدول

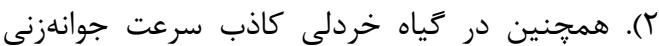

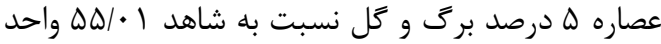

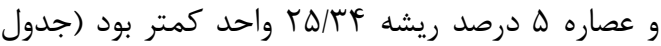


جدول ا- آناليز واريانس يك طرفه و مقايسه ميانكَين درصد جوانهزنى جوى هرز وحشى و خردلى كاذب در سطوح مختلف عصاره آبى بومادران

\begin{tabular}{|c|c|c|c|c|c|c|}
\hline ه درصد & r درصد & ا درصد & شاهد & $\mathrm{F}$ & نوع عصاره & متغير \\
\hline$\cdot / \cdot \mathrm{d}$ & $\mathrm{rr} / \mathrm{qV} \mathrm{c}$ & sN/rrbb & $1 \cdots \mathrm{a}$ & $\Lambda \Delta / \cdot \Lambda^{* * * m}$ & برى & \multirow{4}{*}{ جو هرز } \\
\hline$\cdot / \cdot \mathrm{d}$ & (Tr/Tr & $99 / 9 \mathrm{Vb}$ & $1 \cdots a$ & 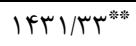 & كل & \\
\hline$r \varepsilon / 9 \vee \mathrm{C}$ & $a \cdot b$ & $91 / 8 \vee a$ & $1 \cdots a$ & $\Lambda \varepsilon / V Y^{* * * *}$ & ريشه & \\
\hline$\cdot 1 \cdots c$ & $\cdot / 19 c$ & $191 \cdot \cdot b$ & $91 / 11 \mathrm{a}$ & $r T V / V Y^{* * * 0 \%}$ & برى & \\
\hline$\cdot / \cdot d$ & $19 / \mu \mathrm{rc}$ & $F r / V \wedge b$ & $91 / 11 a$ & $19 V / 9 V^{*}$ & كل & \multirow[t]{2}{*}{ خردلى كاذب } \\
\hline$\Delta / / 1 / b$ & $\Delta \Delta / \Delta \Delta b$ & $\Delta q / \Gamma r b$ & $91 / 11 \mathrm{a}$ & ||$_{1} / 99^{*}$ & ريشه & \\
\hline
\end{tabular}

**: معنى دارى در سطح احتمال خطاى ا درصد. حروف يكسان در هر سطر بيانكر عدم اختلاف معنىدار بر اساس آزمون دانكن در سطح احتمال خطاى ه درصد مىباشد. جدول r - آناليز واريانس يك طرفه و مقايسه ميانكين سرعت جوانهزنى (بر روز) جوى هرز وحشى و خردلى كاذب در سطوح مختلف عصاره آبى بومادران

\begin{tabular}{|c|c|c|c|c|c|c|}
\hline ه درصد & r درصد & ا درصد & شاهد & $\mathrm{F}$ & نوع عصاره & متغير \\
\hline$\cdot / \cdot d$ & $\Delta / 9 T C$ & $r 1 / 9 r b$ & GT/fra & $r q .1 .91^{\text {*ैa }}$ & برى & \multirow{4}{*}{ جو هرز } \\
\hline$\cdot 1 \cdots c$ & $\cdot / \pi \mathrm{c}$ & $r q / 1 \wedge b$ & Gr/fra & 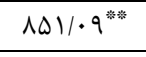 & كل & \\
\hline $9 / 4 \& \mathrm{c}$ & $\Lambda / f C$ & $F V / r I b$ & GT/fra & 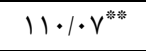 & ريشه & \\
\hline$\cdot / \cdot b$ & $\cdot 1 \wedge \Delta \mathrm{b}$ & $\mathrm{y} / \mathrm{Vb}$ & $\Delta \Delta / \cdot 1 \mathrm{a}$ & $\left\langle 81 / \cdot 9^{* * * *}\right.$ & برى & \\
\hline$\cdot 1 \cdot \cdots c$ & $1 \pi / \Delta \mathrm{Vbc}$ & $r 9 / 49 \mathrm{a}$ & $\Delta \Delta / \cdot 1 \mathrm{a}$ & $r \Delta / \Upsilon^{\text {券絭 }}$ & كل & \multirow[t]{2}{*}{ خردلى كاذب } \\
\hline$r q / q \vee b$ & $r r / 99 b$ & $\Gamma \Delta / q \Gamma b$ & $\Delta \Delta / \cdot 1 \mathrm{a}$ & $r T /\left.\right|^{\text {***; }}$ & ريشه & \\
\hline
\end{tabular}

***: معنى ارى در سطح احتمال خطاى ا درصد. حروف يكسان در هر سطر بيانكر عدم اختلاف معنى دار بر اساس آزمون دانكن در سطح احتمال خطاى ه درصد مىباشد.

جدول ب- آناليز واريانس يكطرفه و مقايسه ميانگين طول ريشهجه (ميلىمتر) جوى هرز وحشى و خردلى كاذب در سطوح مختلف عصاره آبى بومادران

\begin{tabular}{|c|c|c|c|c|c|c|}
\hline ه درصد & r درصد & ا درصد & شاهد & $\mathrm{F}$ & نوع عصاره & متغير \\
\hline$\cdot / \cdot \cdot d$ & . FfFc & $19 / 1 \% b$ & $V r / q \Delta \mathrm{a}$ & 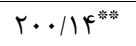 & برى & \multirow{4}{*}{ جوى هرز } \\
\hline$\cdot 1 \cdot \cdots c$ & $\cdot / \cdot \Delta c$ & $19 / 9 \Delta b$ & $V r / 9 \Delta \mathrm{a}$ & 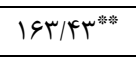 & كل & \\
\hline $\mathrm{r} / 19 \mathrm{~d}$ & N/VVc & $q \Delta / q \vee b$ & $V r / 9 \Delta \mathrm{a}$ & 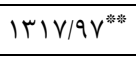 & ريشه & \\
\hline$\cdot / \cdot \mathrm{d}$ & $\cdot / \Delta V c$ & $1 / 99 \mathrm{~b}$ & $r F / q \Delta a$ & 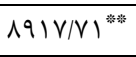 & برى & \\
\hline $.1 \cdots \mathrm{d}$ & I/VFc & $\Delta / \cdot \Delta b$ & $r F / q \Delta \mathrm{a}$ & $111 \mathrm{~V} / \mathrm{Vr}$ **: & كل & \multirow[t]{2}{*}{ خردلى كاذب } \\
\hline Ir/rVd & $r I / F V c$ & rq/^^a & $r F / q \Delta b$ & $\mid \Delta V / \& V^{* * * *}$ & ريشه & \\
\hline
\end{tabular}

***: معنىارى در سطح احتمال خطاى 1 درصد. حروف يكسان در هر سطر بيانكَ عدم اختلاف معنىدار بر اساس آزمون دانكن در سطح احتمال خطاى ه درصد مىباشد.

جدول F- آناليز واريانس يكىطرفه و مقايسه ميانگين طول ساقهجه (ميلىمتر) جوى هرز وحشى و خردلى كاذب در سطوح مختلف عصاره آبى

بومادران

\begin{tabular}{|c|c|c|c|c|c|c|}
\hline ه درصد & r درصد & ا درصد & شاهد & $\mathrm{F}$ & نوع عصاره & متغير \\
\hline$\cdot 1 \cdot \cdots c$ & $\cdot / r \wedge c$ & rg/lTb & $\vee \& / \& \wedge a$ & 1 Ir/G9" & برى & \\
\hline$\cdot / \cdots c$ & $\cdot 1 \cdots c$ & $r q / \wedge b$ & $\vee \& / \varepsilon \wedge a$ & $\mid \Delta V \varepsilon / F \Delta^{* * *}$ & كل & جوى هرز \\
\hline $\mathrm{V} / \mathrm{GC}$ & $1 \cdot 1 \cdot \mathrm{rc}_{\mathrm{c}}$ & $G T / 9 \Delta \mathrm{b}$ & $\vee \varphi / \varepsilon \wedge a$ & TYI/VG"*: & ريشه & \\
\hline$\cdot 1 \cdots \mathrm{c}$ & • & $\cdot / 4 k b$ & १а & $1.9 \mathrm{~N} / \mathrm{AM}$ * & برى & \\
\hline$\cdot / \cdots \mathrm{d}$ & - / fic & $1 / \varepsilon \Delta b$ & $9 \mathrm{a}$ & $\mu F \cdot 91 \cdot \mu^{* * *}$ & كل & خردلى كاذب \\
\hline $1 / \vee \wedge b$ & $1 / \wedge \& b$ & $1 / 9 b$ & १а & $\Delta \cdot 9 V / 9 \Delta^{\text {类米 }}$ & ريشه & \\
\hline
\end{tabular}

***: معنى دارى در سطح احتمال خطاى ا درصد. حروف يكسان در هر سطر بيانكر عدم اختلاف معنى ار بر اساس آزمون دانكن در سطح احتمال خطاى ه درصد مىباشد. 


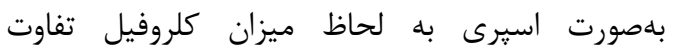
معنى دارى با يكديكر ندارند. نتايج نشان داد ميزان

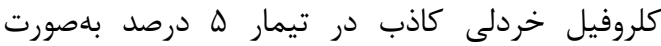

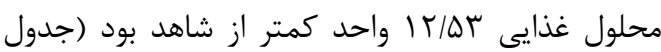

كاهش محتواى كلروفيل در همه غلظتها مى تواند

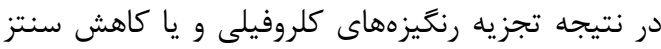

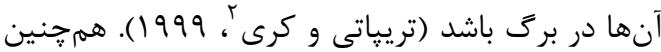

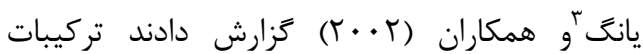

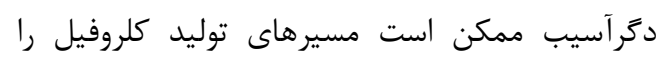

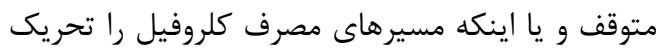
نمايند و يا هر دو واكنش را باعث شوند كه منجر به

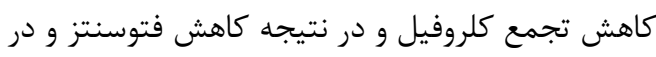
نهايت كاهش رشد كياه كردد.

تأثير عصاره آبى برى بومادران بر صفت سطح برى

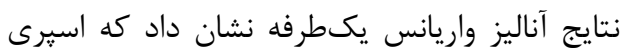
سطوح مختلف عصاره آبى برى بومادران، تفاوت معنى دارى بر سطح برى جوى هرز وحشى و خردلى إنى

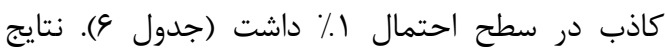
نشان داد اسيرى تيمار ه درصد كه داراى بإيينترين

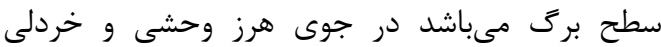

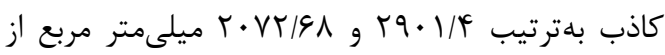
تيمار شاهد كمتر بود. همرجنين اين نتايج براى عصاره

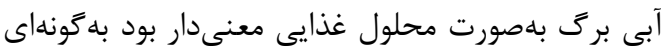

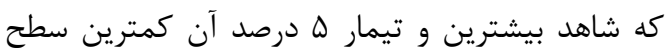

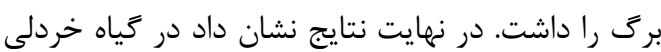
كاذب استفاده از عصاره بهصورت محلول غذايى مؤثرتر از

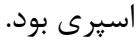
تركيبات دكرآسيب با كاهش تقسيم سلولى و رشد

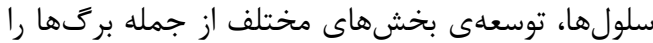

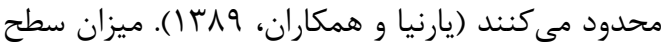

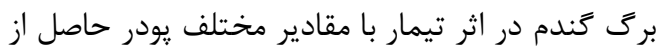

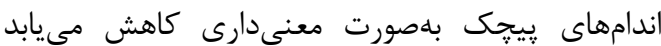

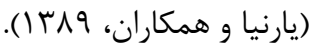

\footnotetext{
${ }^{2}$ Tripathi and Kori
}

${ }^{3}$ Yang
نتايج نشان داد سطوح مختلف عصارهى گياه بومادران اثر معنىدارى بر طول ساقهجه جوى هرز وحشى و خردلى كاذب در سطح احتمال خطاى يك درصد داشت (جدول \&). در زياه جوى هرز وحشى تيمار

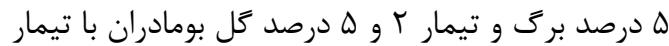

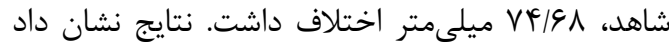
كه در گياه خردلى كاذب عصاره ه درصد برگ، گَل و ريشه بومادران به ترتيب باعث كاهش 9.، 9 و و VITY ميلىمترى طول ساقهجه نسبت به شاهد شدند. كاهش رشد گياه در حضور تركيبات دگر آسيبرسان شيميايى با توقف شديد ميتوز در سلولهاى مريستمى ريشه ٍجه و ساقهجه همراه مىشود و در نتيجه طول ريشه : ونه و

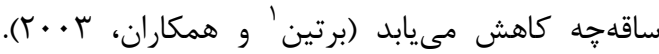
كاهش طول ريشه بيانگر اين نكته است كه طويل شدن سلولها، بلهوسيله مواد دخرآسيب تحت تأثير قرار گرفته است. تخريب توازن هورمونى يكى از مهمترين دلايل

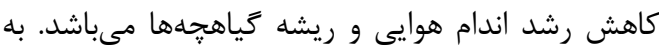
نظر مىرسد عصاره اندامهاى هوايى بومادران حاوى مواد دكرآسيبرسان شيميايى بيشترى نسبت به به ريشه مىباشد. گياه بومادران براى تهيه عصاره در مرحله

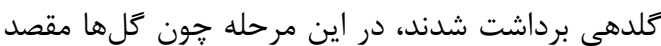
قوى مواد محسوب مىشوند، بيشتر مواد از ريشه به سمت اندام هوايى يعنى برگها و كَلها انتقال مى ميابند.

\section{تأثير عصاره آبى برى بومادران بر ميزان كلروفيل} نتايج نشان داد كه ميزان كلروفيل جوى هرز وحشى برى بردي

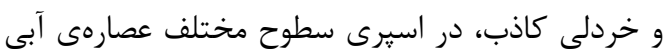

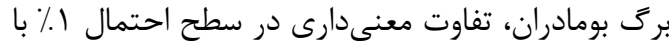

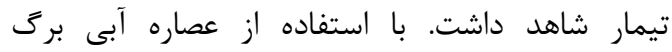
بومادران به حالت اسيرى، كلروفيل جوى هرز وحشى در تيمار ه درصد ب/VF و واحد كمتر از شاهد بود. نتايج مقايسه ميانكَين غلظتهاى مختلف عصاره آبى برى بلصورت اضافه شدن محلول غذايى، همانند اضافه شدن عصاره بلهورت اسيرى آن بود (جدول ه). نتايج مقايسه ميانگين بيانكننده اين است كه در خياه خردلى كاذب، سه تيمار I، Y و له درصد عصارهى آبى برك بومادران

\footnotetext{
${ }^{1}$ Bertin
} 
يزوهشهاى بذر ايران / سال جهارم/ شماره اول / צجسا

جدول ه- آناليز واريانس يك طرفه و مقايسه ميانكين شاخص كلروفيل جوى هرز وحشى و خردلى كاذب در سطوح مختلف عصاره آبى بومادران

\begin{tabular}{|c|c|c|c|c|c|c|}
\hline ه درصد & r درصد & ادرصد & شاهد & $\mathrm{F}$ & نوع عصاره & متغير \\
\hline $11 / r 9 \mathrm{~d}$ & $1 \% / 9 \Delta c$ & $1919 \mathrm{Vb}$ & fra & 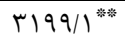 & اسيرى & \multirow{2}{*}{ جو هرز } \\
\hline $1 \cdot 1 / d$ & IF/AFC & IN/V\&b & $\mathrm{fra}$ & TFIF/K & محلول غذايى & \\
\hline rr/rrb & $r / T / b$ & $r g / r b$ & fra & $r q / r^{* * *: 2}$ & اسيرى & \multirow{2}{*}{ خردلى كاذب } \\
\hline ri/fVd & $r \Delta / \cdot \mid c$ & rq/qrb & $\mathrm{fra}$ & YYG/ & محلول غذايى & \\
\hline
\end{tabular}

**: معنى دارى در سطح احتمال خطاى ا درصد. حروف يكسان در هر سطر بيانكر عدم اختلاف معنىدار بر اساس آزمون دانكن در سطح احتمال خطاى ه درصد مىباشد.

جدول 9- آناليز واريانس يكىطرفه و مقايسه ميانكَين سطح برك (ميلىمترمربع) جوى هرز وحشى و خردلى كاذب در سطوح مختلف عصاره آبى

\begin{tabular}{|c|c|c|c|c|c|c|}
\hline ه درصد & r درصد & ا درصد & شاهد & $\mathrm{F}$ & نوع عصاره & كَياه \\
\hline$T M T / V^{c}$ & $r \Delta T / T^{c}$ & $r r \Delta / q^{b}$ & $r|r y /|^{a}$ & $r \Delta \Gamma \cdot \Gamma / T^{* * * * *}$ & اسيرى & \multirow{2}{*}{ جوى هرز } \\
\hline$r \Delta q / q \mu^{c}$ & $r \wedge T / \Delta V^{c}$ & $r \Delta F / F q^{b}$ & $r|r F /|^{a}$ & 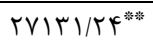 & محلول غذايى & \\
\hline $1.91 / 4 Y^{d}$ & $|\Delta| \cdot \mid \Lambda \Lambda^{c}$ & $1 \Delta \xi \xi / \mu^{b}$ & $r|r y /|^{a}$ & $1 \Delta f \cdot 1 / 9 V^{* * *}$ & اسيرى & \multirow[b]{2}{*}{ خردلى كاذب } \\
\hline$\Lambda F \cdot / r v^{d}$ & $\| V F / V F^{c}$ & IFVN/TRb & $r \mid r y / l^{a}$ & $r \mid \Delta V V / q^{* * *}$ & محلول غذايى & \\
\hline
\end{tabular}

**: معنى دارى در سطح احتمال خطاى ا درصد. حروف يكسان در هر سطر بيانكر عدم اختلاف معنىدار بر اساس آزمون دانكن در سطح احتمال خطاى هـ درصد مىباشد.

بر ويزگگىهاى ظهور و رشد نهال هاى استيى و علف ليمو نشاندهنده كاهش معنى

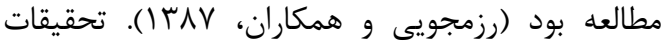
نشان داد غلظتهاى مختلف عصارهى اسفند سبب كاهش معنىىارى در وزنتر ساقههاى تاجخروس و دون يولاف وحشى مىشود، هر جند اين كاهش در برخى ونى غلظتها معنى دار نمىباشد (مكىزاده تفتى و همكاران، 911) علفهاى هرز تاجخروس و سلمهتره نشان داد كه عصاره برگ و بنه زعفران سبب كاهش وزنتر ساقه هر دو علف

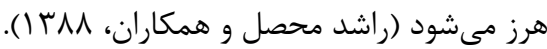

تأثير عصاره آبى برى بومادران بر وزن خشك

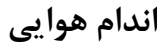
نتايج نشان داد كه اسيرى عصارهى آبى برى بومادران اثر معنىدارى بر وزن خشك اندام هوايى جوى هرز وحشى و خردلى كاذب در سطح احتمال 1. داشت (جدول ^). نتايج مقايسه ميانگين نشان داد در جوى

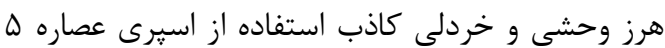

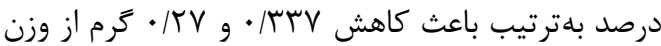
خشك اندام هوايى نسبت شاهد شد. اين نتايج همرجنين

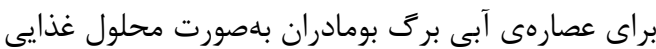

تأثير عصاره آبى برى بومادران بر وزنتر اندام هوايى

نتايج آناليز واريانس يكطرفه حاكى از آن است كه

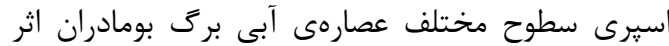
معنى

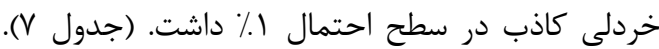

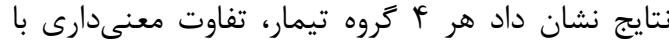

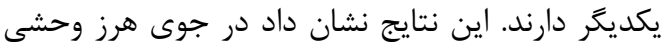

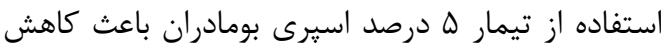

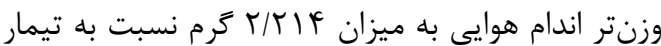

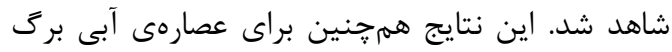

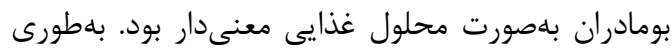
كه در جوى هرز وحشى تيمار شاهد بيشترين و تيمار

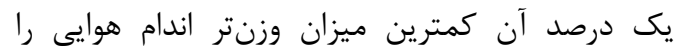
داشت. در كياه خردلى كاذب در عصارهى اضافهشده بهصورت اسيرى بيشترين وزنتر اندام هوايى براى شاهد ديد

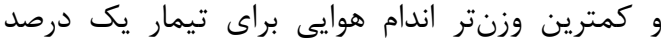
مشاهده ترديد در حالى كه در عصارهى اضافهشده

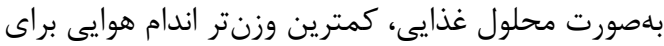
تيمار ل ال درصد مشاهده شد.

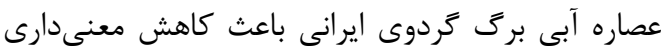
در وزنتر ساقهى تاجخروس و خرفه مىشود (اميدى و

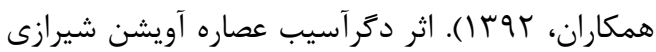


محمدزاده نصر آباد عليا و مهتدى: ارزيابى توان دكر آسيبى عصارهى آبى بومادران...

\begin{tabular}{|c|c|c|c|c|c|c|}
\hline ه درصد & r درصد & ا درصد & شاهد & $\mathrm{F}$ & نوع عصاره & كياه \\
\hline$\cdot / \cdot \wedge \Leftrightarrow \mathrm{d}$ &.$/ 1 \mathrm{fc}$ &.$/ 19 b$ & $r / r a$ & rIrVV/99**** & اسيرى & \multirow{3}{*}{ جوى هرز } \\
\hline $.119 \mathrm{c}$ & $\cdot / r \Delta b$ &.$/ 11 \mathrm{~d}$ & $r / r a$ & GIKY/GV & محلول غذايى & \\
\hline $1 / \Delta \mathrm{c}$ & $1 / \wedge 9 b$ & $1 / r V d$ & $r / r a$ & $r / \Delta / 9 \Delta^{\text {*** }}$ & اسيرى & \\
\hline$\cdot / v \Delta d$ & $\cdot / \wedge 9 \mathrm{c}$ & $1 / \cdot \Delta b$ & $r / r a$ & $1 \wedge r \cdot 199^{* * *}$ & محلول غذايى & خردلى كاذب \\
\hline
\end{tabular}

***: معنىارى در سطح احتمال خطاى ادرصد. حروف يكسان در هر سطر بيانكر عدم اختلاف معنىدار بر اساس آزمون دانكن در سطح احتمال خطاى ه درصد مىباشد.

جدول ^- آناليز واريانس يكطرفه و مقايسه ميانكين وزن خشك (كرم) اندام هوايى جوى هرز وحشى و خردلى كاذب در سطوح مختلف عصاره آبى برى بومادران

\begin{tabular}{|c|c|c|c|c|c|c|}
\hline ه درصد & r درصد & ا درصد & شاهد & $\mathrm{F}$ & نوع عصاره & كَياه \\
\hline $.1 \cdot 1 \mathrm{rc}$ & $\cdot 1 \cdot r b c$ & $\cdot / \cdot r b$ & $\cdot / r \Delta \mathrm{a}$ & $r \nvdash \Lambda \cdot / K^{\prime *}$ & اسيرى & \multirow[b]{2}{*}{ جوى هرز } \\
\hline$\cdot 1 \cdot 1 \mathrm{Vb}$ & $\cdot 1 \cdot r r b$ & $\cdot / \cdot 19 \mathrm{~b}$ & $\cdot / r \Delta a$ & rrr./9 & محلول غذايى & \\
\hline$\cdot / \cdot \wedge d$ & $\cdot / 1 r b$ & $\cdot / 1 \mathrm{rc}$ & $\cdot / r \Delta \mathrm{a}$ & GTV/qu"*:*: & اسيرى & \multirow{2}{*}{ خردلى كاذب } \\
\hline$\cdot / \cdot v \Delta d$ & $.1 .9 c$ & $\cdot / 1 r b$ & $\cdot / r \Delta \mathrm{a}$ & $\mid M T F / T^{* * *}$ & محلول غذايى & \\
\hline
\end{tabular}

**: معنىارى در سطح احتمال خطاى ادرصد. حروف يكسان در هر سطر بيانكر عدم اختلاف معنىدار بر اساس آزمون دانكن در سطح احتمال خطاى ه درصد مىباشد..

برنجاسف باعث كاهش معنى دارى وزن خشك ساقه گه و ريشهجه بار هنَ مىشود.

\section{تأثير عصاره آبى برت بومادران بر وزنتر ريشه}

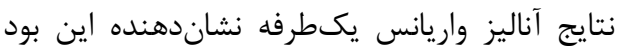
كه در وزنتر ريشه جوى هرز وحشى و خردلى كاذب، در اسيرى سطوح مختلف عصارهى آبى برى بـ بومادران،

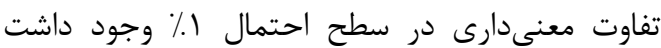
(جدول 9). نتايج نشان داد وزنتر ريشه در اسيرى تيمار

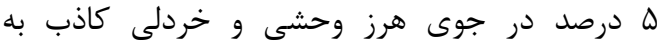

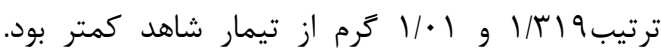
نتايج تجزيه واريانس براى عصارهى آبى برك بومادران

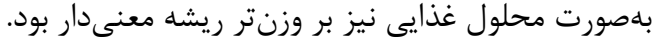

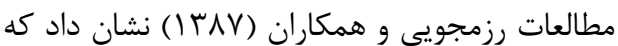
اثر دكرآسيب عصاره آويشن شيرازى باعث كاهش

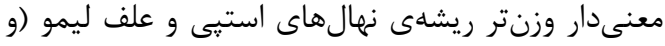
البته تأثيريذيرى كمتر كَونه استيى در مقايسه با علف ليمو) مىشود كه با نتايج اين آزمايش مطابقت داشت.
معنىدار بود. در كياه جوى هرز وحشى نتايج مقايسه ميانكَين نشان داد كه ب غلظت ا، ب و و ه درصد عصارهى

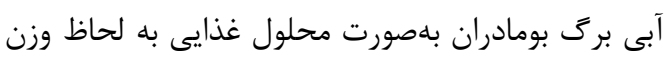

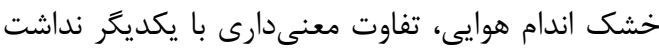

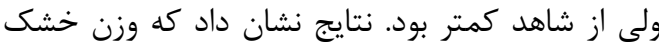

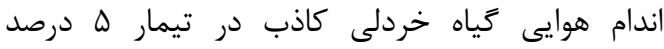
عصارمى آبى برى بومادران بلهصورت محلول غذايى إن / FVD كاهش وزن خشك بخش هوايى مىتواند به علت كاهش جذب عناصر غذايى و آب توسط ريشه، كاهش برك براى فتوسنتز و همهنين كاهش ميزان فتوسنتز توسط مواد دكر آسيبرسان شيميايى باشد كه در نتيجه،

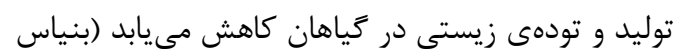

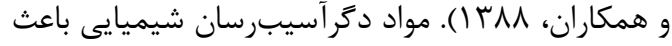
ايجاد تنشهاى ثانويه (كاهش جذب آب آب و مواد غذايى و و تنش شورى) در كياهان مىشوند كه در نتيجه كاهش

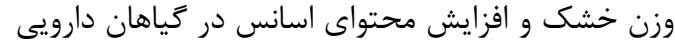

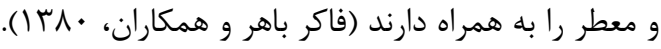

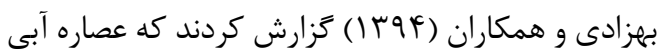


مجله يزوهشهاى بذر ايران / سال جهارم/ شماره اول / ع عا

جدول 9- آناليز واريانس يكطرفه و مقايسه ميانكَين وزن تر (كرم) ريشه جوى هرز وحشى و خردلى كاذب در سطوح مختلف عصاره آبى برى بومادران

\begin{tabular}{|c|c|c|c|c|c|c|}
\hline ه درصد & r درصد & ا درصد & شاهد & $\mathrm{F}$ & نوع عصاره & كياه \\
\hline.$/ \cdot v 1 c$ & $.1 \cdot 9 \mathrm{c}$ & $\cdot / \pi r b$ & $1 / 49 a$ & $r V \cdot 1 / r^{* * * *}$ & اسيرى & \multirow{3}{*}{ جوى هرز } \\
\hline$\cdot / r V b$ & $\cdot / r \cdot c$ &.$/ 19 c$ & $1 / r 9 a$ & $r|\Delta \varphi| \cdot \varphi^{* * * *}$ & محلول غذايى & \\
\hline$\cdot / r \wedge d$ & $1 / 4 f a$ & $1 / T T C$ & $1 / \pi 9 b$ & 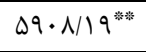 & اسيرى & \\
\hline$\cdot / \cdot \operatorname{vad}$ & $\cdot / 1 \mathrm{rc}$ & $\cdot / \pi q b$ & $1 / 49 a$ & ITAKG/KG"*** & محلول غذايى & خردلى كاذب \\
\hline
\end{tabular}

**: معنى دارى در سطح احتمال خطاى ادرصد. حروف يكسان در هر سطر بيانكر عدم اختلاف معنى دار بر اساس آزمون دانكن در سطح احتمال خطاى هـ درصد مىباشد..

جدول • ا- آناليز واريانس يكىرفه و مقايسه ميانكَين وزن خشك ريشهى (كرم) جوى هرز وحشى و خردلى كاذب در سطوح مختلف عصاره آبى برى بومادران

\begin{tabular}{|c|c|c|c|c|c|c|}
\hline ه درصد & r درصد & ا درصد & شاهد & $\mathrm{F}$ & نوع عصاره & كياه \\
\hline$\cdot / \cdot \Delta d$ &.$/ .1 \% \mathrm{c}$ & $\cdot / \cdot r b$ &.$/ 1 r f a$ & 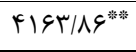 & اسيرى & \multirow{4}{*}{ جوى هرز } \\
\hline $.1 \cdot r r b$ & $.1 \cdot T \& b$ &.$/ \cdot 1 \Delta \mathrm{c}$ &.$/ 1 \mathrm{rfa}$ & $\mid \Delta V G / F \Delta^{* \% *}$ & محلول غذايى & \\
\hline $.1 .49 \mathrm{~d}$ &.$/ 1 F F b$ & $.11 .9 \mathrm{c}$ &.$/ 1 \mathrm{rfa}$ & $r \Lambda \cdot / \Lambda r^{* * *}$ & اسيرى & \\
\hline.$/ \cdot 1 \Delta d$ &.$/ \cdot r V C$ &.$/ \cdot r \varphi b$ &.$/ 1 \mathrm{rfa}$ & $r \vee q \cdot / r q^{* * *}$ & محلول غذايى & \\
\hline
\end{tabular}

**: معنى دارى در سطح احتمال خطاى ادرصد. حروف يكسان در هر سطر بيانكَ عدم اختلاف معنى دار بر اساس آزمون دانكن در سطح احتمال خطاى هـ درصد مىباشد..

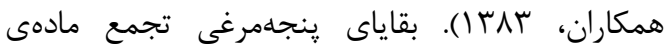
خشك در ريشه و بخش هوايى گندم و يولاف را تحت

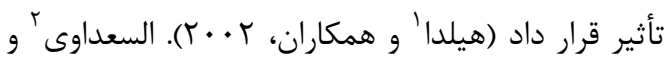

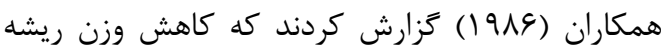
همسو با كاهش كلروفيل و جذب يونها مىباشد.

\section{نتيجه گَيرى}

در اين مطالعه عصارمى آبى گياه دارويى بومادران

باعث تغييراتى در روند جوانهزنى و رشد جوى هرز و خردلى كاذب شد كه اين تغييرات بيانگر اثرات

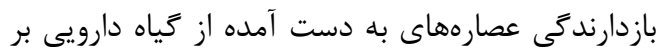
علفهاى هرز بود. در هر دو نوع كشت، عصارههاى به

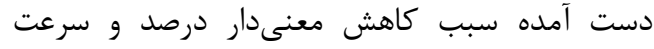
جوانهزنى بذرهاى جوى هرز وحشى و خردلى كاذب شدند و حتى در برخى غلظتها (ه درصد گل و برى برى) اين كاهش به صفر رسيد. همرجنين طول ساقه

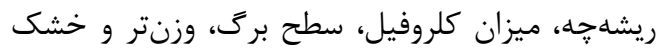

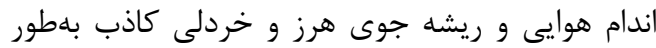
معنىدارى نسبت به تيمار شاهد كاهش يافت. روند

${ }^{1}$ Hilda

${ }^{2}$ Al-Saadawi
تأثير عصاره آبى برَ بومادران بر وزن خشك ريشه نتايج آناليز واريانس نشان داد در وزن خشك ريشه جوى هرز وحشى و خردلى كاذب، در اسيرى سطوح

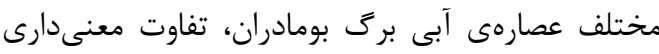
در سطح احتمال 1\% وجود داشت (جدول • •). نتايج نشان داد هر \& ₹روه تيمار تفاوت معنى دارى با يكديكر داشتند. در ادامه نتايج مشخص كرد كه وزن خشك خره ريشه جوى هرز وحشى و خردلى كاذب در اسيرى تيمار

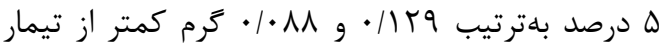
شاهد بود. اين نتايج همرجنين براى عصارهى آبى برى

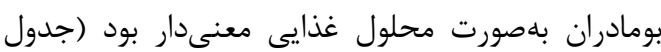

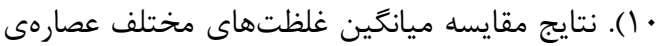
آبى برگ بومادران بهصورت محلول غذايى بهَّنهاى بود كه در جوى هرز وحشى، تيمار شاهد بيشترين و تيمار يك درصد آن كمترين وزن خشك ريشه و در خردلى كاذب تيمار ه درصد آن كمترين وزن خشك ريشه ران ران

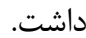
اسانس برگ گَياه دارويى مورخوش اثر بازدارندگى بر

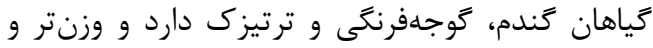
خشك را در اين زياهان كاهش مىدهد (سلطانىيور و 
محمدزاده نصر آباد عليا و مهتدى: ارزيابى توان دكر آسيبى عصارهى آبى بومادران...

مىتواند در توليد علفكشهايى با منشأ طبيعى مورد استفاده قرار تيرد.

$$
\text { سياسگزارى }
$$

نثخارندكان از دانشعاه ياسوج به خاطر حمايت مالى

$$
\text { يزوهش حاضر قدردانى مىنمايند. }
$$

كاهشى و ميزان بازدارندگى عصارهها با افزايش غلظت،

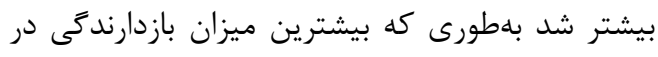

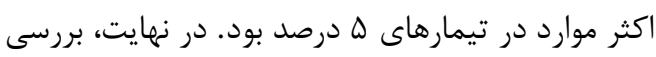

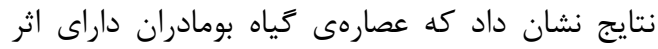

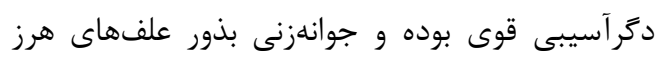

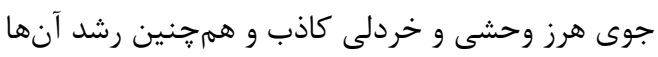

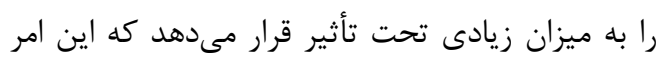

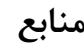

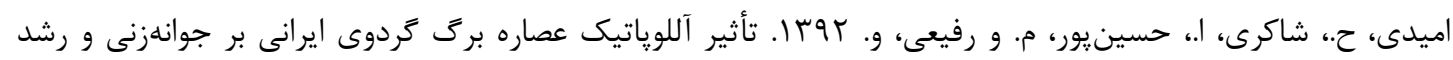

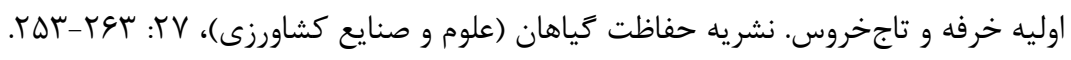

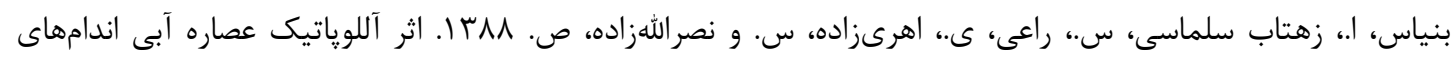

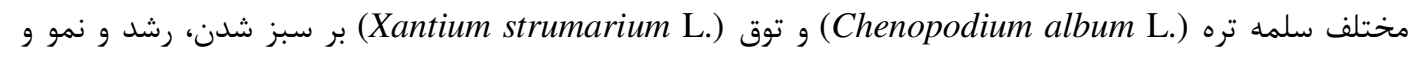

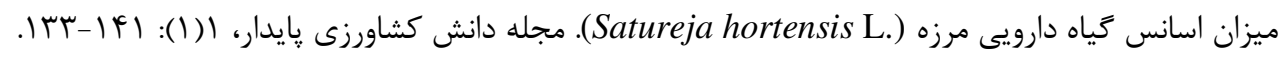

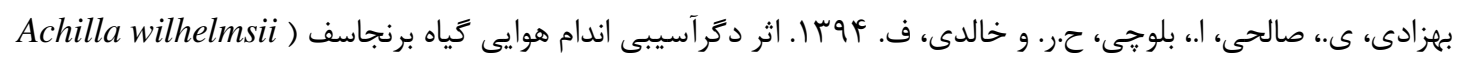

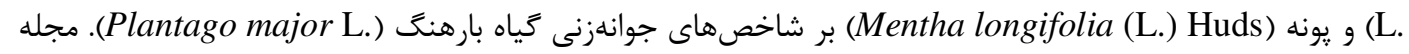

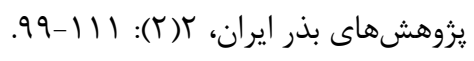

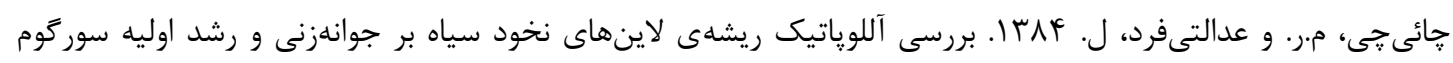

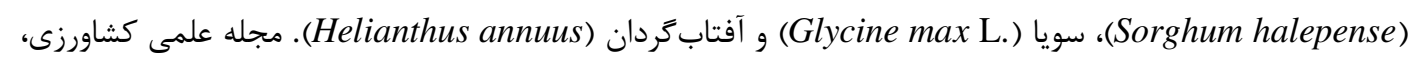

$.99-\mathrm{\vee}: \mathrm{r \Lambda}$

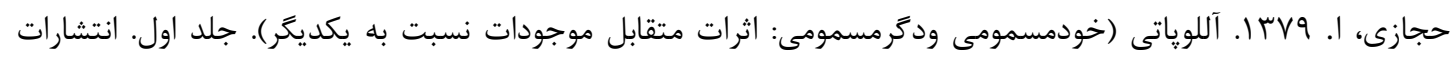

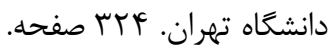

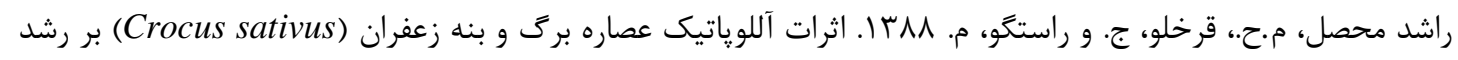

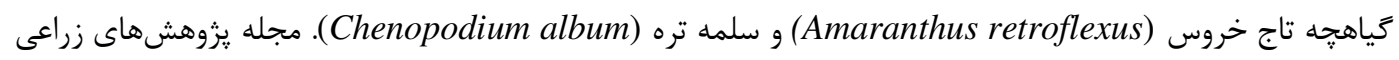

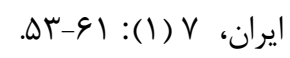

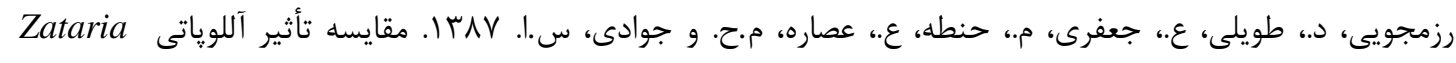

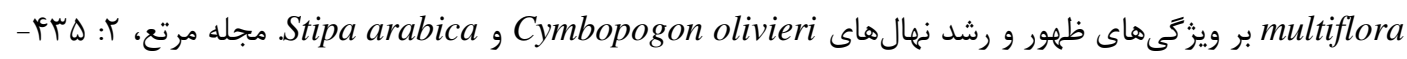

. FT

رئوففرد، ف.، و اميدبيگى، ر. •وبا. بررسى خاصيت آللوياتيك پيكر رويشى گياه سنبل ختابى ( Angelica (archangelica L.

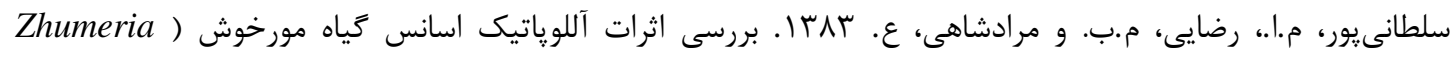

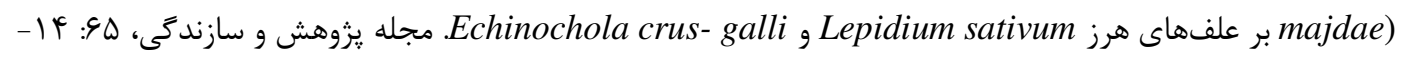


عزيزى، م.، عليمرادى، ل. و راشد محصل، م. هیَّا. اثرات آللوياتى اسانس Bunium persicum و Cuminum cyminum

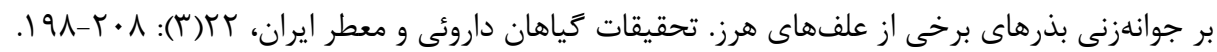

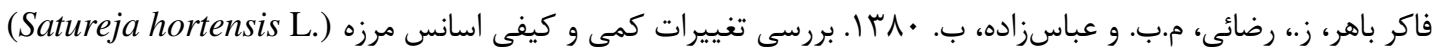

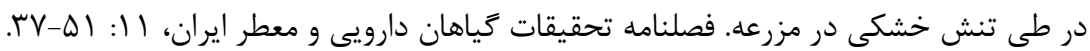

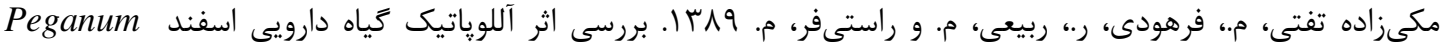

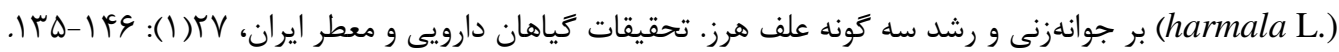

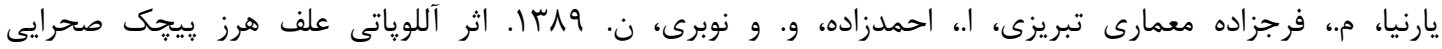
(Convolvulus arvensis L.)

Alam, S.M., and Islam, E.U. 2002. Effect of aqueous extract of leaf stem and root of nettle leaf goosefoot and $\mathrm{NaCl}$ on germination and seedling growth of rice. Pakistan Journal of Science and Technology, 1(2): 47-52.

Al-Saadawi, I.S., Al-Hadithy, S.M. and Arif, M.B. 1986. Effects of three phenolic acids on chlorophyll content and ions uptake in cowpea seedlings. Journal of Chemical Ecology, 12: 221-227. https://doi.org/10.1007/BF01045605

Bertin, C., Yang, X. and Weston, L.A. 2003. The role of root exudates and allelochemicals in the rhizosphere. Plant and soil, 256: 67-83. https://doi.org/10.1023/A:1026290508166

De Feo, V., De Simone, F., and Senatore, F. 2002. Potential allelochemicals from Ruta graveolens. Phytochemistry, 61(5): 573-578. https://doi.org/10.1016/S0031-9422(02)00284-4

Fujii, Y., Furukawa, M., Hayakawa, Y., Sugawara, K. and Shibuya, T. 1991. Survey of Japanese medicinal plants for the detection of allelopathic properties. Journal of Weed Research Japan, 36: 36-42. https://doi.org/10.3719/weed.36.36

Hassannejad, S. and Ghafari, S.B. 2013. Allelopathic effects of some Lamiaceae on seed germination and seedling growth of dodder (Cuscuta campestris Yunck.). International Journal of Biosciences, 3(3): 9-14. https://doi.org/10.12692/ijb/3.3.9-14

Hilda, G.G., Francisco, Z.G., Maiti, R.K., Sergio, M.L., Elia, L.D. and Salomon, M.L. 2002. Effect of extract of Cynodon dactrylon L. and Sorghum halepans L. on cultivated plants. Crop Research, 23: 382-388.

Iqbal, J. and wright, D. 1999. Effect of weed competition on flag leaf photosynthesis and grain yield of spring wheat. Journal of Agricultural Science, 123: 23-30. https://doi.org/10.1017/S0021859698006066

Maguire, J.D. 1962. Speed of germination-aid in selection and evaluation for seedling emergence and vigour. Crop Sciences, 2(2): 176-177. https://doi.org/10.2135/cropsci1962.0011183X000200020033x

Sharafzadeh, S.H. 2013. Major constituents of the volatile oils of genus Achillea from Iran. Scientia Agriculturae, 2: 1-2.

Singh, H.P., Batish, D.R. and Kohi, R.K. 2006. Hand book of sustainable weed management.CRC Press.

Tripathi, S.A. and Kori, D.C. 1999. Allelopathic evolution of Tectona grandis leaf, root and soil aqua extracts on soybean. Indian Journal Forestry, 22: 366-374.

Vyvyan, J.R. 2002. Allelochemicals as leads for new herbicides and agrochemicals. Tetrahedron, 58: 1631-1646. https://doi.org/10.1016/S0040-4020(02)00052-2 


$$
\text { محمدزاده نصر آباد عليا و مهتدى: ارزيابى توان دكر آسيبى عصارهى آبى بومادران... }
$$

Yang, C.M., Lee, C.N. and Zhou, C.H. 2002. Effects of three allelopathic phenolics on chlorophyll accumulation of rice (Oryza sativa) seedlings: I. Inhibition of supply orientation. Institute of Botany. Academic Sinica. Nankang, Taipei, Taiwan. 


\title{
An Investigation into the Effect of Allelopathic Potential of Achillea wilhelmsii on Germination and Growth of Hirshfeldia incana and Hordeum glaucum
}

\author{
Zahra Mohammadzadeh Nasrabad Olya ${ }^{1}$, Ahmad Mohtadi ${ }^{2, *}$ \\ ${ }^{1}$ Graduated Student, Department of Biology, Faculty of Science, Yasouj University, Yasouj, \\ Iran \\ ${ }^{2}$ Assistant Professor, Department of Biology, Faculty of Science, Yasouj University, Yasouj, \\ Iran \\ "Corresponding author, E-mail address: a.mohtadi@yu.ac.ir
}

(Received: 12.06.2016 ; Accepted: 18.02.2017)

\begin{abstract}
Weeds pose a serious threat to farmers. Using allopathic properties of the plants, especially those of the medicinal plants, has an important role in controlling weeds. This study was conducted to examine the allelopathic potential of Achillea wilhelmsii in germination of Hirshfeldia incana and Hordeum glaucum. A factorial experiment was conducted, adopting a completely randomized design with three replicates in both libratory and pot cultivation. Organ extracts (flower, leaf and root) of Achillea wilhelmsii in four concentrations were used, namely: 1, 2 and 5\%. In addition, distilled water was used as a control. The result showed that the greatest percentages of the germination of Hordeum glaucum and Hirshfeldia incana were in the distilled water, which were 100 and $91 \%$, respectively and that their germination reached zero percent under extraction of leaf and flower with a concentration of $5 \%$. The concentration higher than $2 \%$ of the extraction of Achillea wilhelmsii significantly decreased germination, length of radicle and aerial part, fresh and dry weight of shoot and root, leaf area index and amount of chlorophyll in Hordeum glaucum and Hirshfeldia incana, in contrast with distilled water. The results showed that leaf and flower extraction of Achillea wilhelmsii had allopathic effects. In addition, it had impacts on germination and growth of the seeds of Hordeum glaucum and Hirshfeldia incana, which could be used in the production of natural herbicides.
\end{abstract}

Keywords: Achillea wilhelmsii, Hordeum glaucum, Hirshfeldia incana, Natural herbicide, Medicinal plant

\section{Highlights:}

1- Aqueous extrac of Achillea wilhelmsii significantly decreases germination and growth of Hordeum glaucum and Hirshfeldia incana.

2- Aqueous extrac of Achillea wilhelmsii can be used to produce the natural herbicides. 